\title{
Learning from each other
}

The role of libraries in the promotion of international understanding

A

CRL's vision is that of a future where academic and research librarians and libraries are essential to a thriving global community of learners and scholars. ${ }^{1}$ In today's world, no community can exist alone. We live in an interdependent world. We need to understand each other, cooperate, and work towards mutual benefits.

In such a context of interdependence, the current pandemic has shown that the COVID-19 virus knows no geographical or racial boundaries. The search for a vaccine to control the virus has also required a collaborative international effort. Businesses are involved in the import and export of products from many different countries. Education is a global business with students and scholars traversing national borders to seek and share knowledge. Similarly, libraries provide access to resources and services that may have originated or been developed in some countries, and users may be remotely accessing them from other countries. We live in a global community.

However, there have also been barriers to this international collaboration, such as insinuations and accusations of some countries being originators of the COVID-19 virus and deliberately spreading it, interference in another country's political processes, economic unfairness in trade, hacking into websites, etc. While some of these may be true, others are based on hearsay, assumptions, and unconfirmed reports. To understand and/or counter these, requires an understanding of the other side's cultures, practices, and ways of life. Herein lies the role of libraries in facilitating learning from each other and promoting international understanding.

International understanding engages reciprocity, moving beyond local and national viewpoints to an awareness and recognition of each other's ways of life. It involves developing a broader international outlook and an acceptance of other ways of knowing and doing. It can also include an understanding of the practices, problems, and solutions by others. While it is important to retain our own identities, we also need to respect other cultures, values, and ways of life. According to Hofstede's Cultural Framework, there is wide variation in cultures that include six dimensions: power distance (high versus low), individualism versus collectivism, masculinity versus femininity, uncertainty avoidance index, long-term versus short-term orientation, and indulgence versus restraint. ${ }^{2}$ For example, the United States scores very high on individualism but rather low on long-term orientation, whereas a country like China scores low on individualism but high on long-term orientation. ${ }^{3}$ There is, thus, a need to understand these differences and accept them. Acceptance does not necessarily mean agreement, but an understanding that others may engage differently. With increasing global interdependence among people and nations, respect for others brings about respect for ourselves.

U.S. college and university libraries play host to large numbers of visitors from all over the world. According to Opendoorsdata.org, there were nearly 1.1 million international students enrolled in U.S. colleges in 2019-20, representing $5.5 \%$ of the total U.S. student body. ${ }^{4}$ While the student numbers

Diljit Singh is retired professor at University of MalayaKuala Lumpur in Malaysia, email: diljit.singh.dr@gmail. com

(c) 2021 Diljit Singh 
decreased by $1.8 \%$ (from $1,095,299$ to $1,075,496$ ) due to the COVID-19 pandemic and social and policy factors, they still represent $5.5 \%$ of the total U.S. student body. In addition to students, there are visiting and exchange scholars, and individuals or groups who come to the United States for study visits. These visitors come from many different countries with their own backgrounds, experiences, beliefs, practices, and norms. Some are non-native English-speaking, but rich in their own cultures. All these visitors present opportunities for learning from each other, of which libraries and librarians can take advantage.

Lev Vygotsky's concept of social constructivism suggests that social and cultural interactions also play a part in learning. ${ }^{5}$ Through interactions with international visitors, there are opportunities for the hosts to learn about other cultures, norms, challenges and solutions, and innovative practices that can be applied at home. A better understanding of the visitors' culture and ways of life can help provide better insights for the hosts and, at the same time, better learning experiences for the visitors. For example, an understanding of the religious practices and norms of visitors' faiths - be it Mus$\mathrm{lim}$, Jewish, Hindu, or other-can promote better relationships on both sides, thereby contributing to international understanding.

The call for libraries to be involved in promoting international understanding has been expressed many times. Almost 75 years ago, Felix E. Hirsch wrote in College and Research Libraries about the need for libraries to play a role in international understanding. He quoted U.S. scholar-librarian William Warner Bishop, who said "every effort made in each individual library for a better appreciation of the culture of other peoples, every formal attempt at international cooperation, every personal gesture of friendship, counts in the great cause of freedom."

More recently, there have been discussions in the literature on diversity initiatives as they pertain to staffing, culture, collections, services, and programming in academic libraries ${ }^{7}$ to promote international understanding. There have also been studies showing that the library is vital to supporting international students' transition to life and study at a host university. The challenges international students experience generally relate to unfamiliarity with the socio-cultural environment and the academic and library practices at their host universities, rather than educational shortcomings. ${ }^{8}$

International understanding is a two-way process. The students and visitors who come from different countries contribute to the Unites States in many ways. They contribute economically through tuition and fees, textbooks and educational materials, food, housing, transportation, clothing, and other expenditures. Graduate students and scholars also contribute to the development of new knowledge through their research. Many of these students and scholars will return to their home countries upon graduation or completion of their visits, but those who wish to stay on present opportunities for the United States to recruit the best talent from across the world. Those who do return home carry with them not just memories of their stay, but also knowledge of U.S. products and services which they may continue to acquire back home, thus making further contributions to the U.S. economy.

Going beyond the economic contributions, students and visitors from abroad provide opportunities for interactions with locals, which can lead to shedding of stereotypes, exploring new perspectives, and gaining cross-cultural skills. ${ }^{9}$ They also help to build culturally diverse learning environments. While most students and visitors who come to the United States will have a certain level of proficiency in the English language to meet the university entrance requirements, many will also be proficient in the language(s) of their home country. This can be a beneficial resource to the international language departments of the university, or even to the wider campus community who wish to learn an international language at the conversational level. The students and visitors also add diversity of ideas and viewpoints, be it in formal classroom sessions or informal discussions in the cafeteria.

There are thus great opportunities for the library community and wider campus to understand each other and contribute to better international understanding. This also resonates with the U.S. Department of Education's aim of preparing the country for a globalized world and to engage with the international community, as envisaged in their 
publication Succeeding Globally through International Education and Engagement. ${ }^{10}$

Libraries and librarians can help enhance understanding among international visitors, the library, and wider campus community in a variety of ways. Libraries generally provide learning opportunities through their resources and services to students and visitors from abroad. Similarly, there are opportunities for librarians and libraries to learn from these visitors. Learning is not confined to just books and databases. It is a two-way process. Librarians get to "visit" other countries, break down barriers and overcome stereotypes, perhaps learn a few words of an international language, and create an environment for the sharing of knowledge that can be mutually beneficial to both sides. As Stephen Covey so cogently points out in The 7 Habits of Highly Effective People, it is important to "first to understand, then to be understood." 11

Libraries can work towards developing international understanding in many ways. They can develop their collections and services to meet the needs of international students and visitors. Many of these visitors want to learn something that they can relate to or apply back in their home countries. Thus, having access to resources about their home country can be of great help to them. Displays, exhibits, and guest presentations can help the campus community learn more about other countries, cultures, and issues in those countries.

The personal contacts U.S. librarians make with students, visiting scholars, and others provide opportunities to make connections across the globe. They serve not just for exchange of ideas and professional development, but also travel opportunities in the future. This can facilitate staff exchanges, book donations, and avoid wastage in aid programs. Hence, the host country benefits in many ways, too.

There is much libraries can do to improve the experiences of international students, especially the younger ones and during the uncertainty of the COVID-19 pandemic, on their campuses. These students often face problems of adjustment, many being away from home for the first time. They have been used to certain ways of life. Libraries can also provide local information on the city, such information on where these visitors can find something, be it international food stores, places of worship, local COVID-19 pandemic measures and resources, or other information needs. With graduate students and visiting scholars, there are opportunities for greater engagement and collaboration. They are usually more mature, have experience back home, and can serve as guest speakers or resource persons for projects or programs that can be mutually beneficial.

There are also many alumni who have returned home and contribute to the development of their home countries. Some go on to positions of leadership in their institutions or professions at home-be it in politics, government, academia, business, performing arts, or other areas-and make contributions not only to the home country but also internationally. This again provides opportunities for learning from each other and for international cooperation.

It is important to note with the ongoing COVID-19 pandemic that librarians are ensuring that international students and scholars are adjusting to local safety measures, obtaining online academic resources, accessing safe study spaces and being informed of changing COVID-19 academic guidelines, whether they are on campus or are temporarily at home. Conversely, international students and scholars are a source of information for host campuses to learn of different responses to the pandemic by providing their personal and country experiences.

There are thus many avenues for libraries and librarians to contribute to a better world by learning from each other. International students, scholars, and visitors can share their knowledge and experiences with their hosts. Alumni represent a rich resource for learning from those who have returned to their home countries. For librarians, conversations, exchange visits, and international conferences provide opportunities to become aware and learn firsthand about other countries. Libraries and librarians can make a difference in promoting international understanding.

\section{Notes}

1. ACRL Plan for Excellence (Chicago: ACRL, 2011, rev. 2019), www.ala.org/acrl/aboutacrl /strategicplan/stratplan.

(continues on page 174) 
Literary Awards, and resources we had not thought about, such as student government resources. We recognized our limitations, as we are not a part of the communities we were trying to support.

\section{Impact and next steps}

We recognize that we are at a starting place for promoting inclusivity and diverse collections. Although we saw increases in views of the guides tied to when they were promoted on social media, our goal is to meet needs on campus and highlight the lived experiences of underrepresented communities, as well as resources that support and celebrate these communities. We want to make sure that we can continue to maintain online resource guides to meet the needs of our patrons and plan to grow our partnerships with organizations on campus during and post-COVID-19.

Our process was not as smooth and was not as ideal as we would have liked. We were pushed with time and would have liked to have had more extended conversations with people in order to promote these areas of the collection. However, our reflection on our process has allowed us to see areas of improvement and has helped guide us with our next steps. With promoting inclusivity, we recognize that this is an on-going process and not a one-time activity.

\section{Notes}

1. ACRL, "Diversity Standards: Cultural Competency for Academic Libraries," May 4, 2012, www. ala.org/acrl/standards/diversity.

2. ALA, "Diverse Collections: An Interpretation of the Library Bill of Rights," July 26, 2006, www.ala. org/advocacy/intfreedom/librarybill/interpretations/ diversecollections.

3. Clemson Libraries, "Latinx Voices and Readings," September 11, 2020, https://clemson.libguides. com/latinxvoices.

4. Clemson Libraries, "LGBT+ Voices and Readings," October 5, 2020, https://clemson.libguides. com/LGBTQ. $\approx$

("Learning from each other," continued from page 170)

2. Gert Hofstede, "Dimensionalizing cultures: The Hofstede model in context," Online Readings in Psychology and Culture 2, no. 1 (2011), https:// doi.org/10.9707/2307-0919.1014.

3. Hofstede Insights, "Country Comparison," Hofstede Insights (n.d.), https://www.hofstede -insights.com/country-comparison/ (accessed February 9, 2021).

4. Institute of International Education, "International Student Enrolment Trends, 1948/492019/20," Open Doors Report on International Educational Exchange (2020), https://opendoorsdata.org/data/international-students/enrollmenttrends/ (accessed February 21, 2021).

5. Chu Chih Liu, and I. Ju (Crissa) Chen, "Evolution of Constructivism," Contemporary Issues in Education Research 3, no. 4 (2010): 63-66, https://doi.org/10.19030/cier.v3i4.199.

6. Felix E. Hirsch, "College Libraries and International Understanding," College \& Research Libraries 7, no. 2: 138-44.

7. Alice M. Cruz, "Intentional Integration of
Diversity Ideals in Academic Libraries: A Literature Review," The Journal of Academic Librarianship 45, no. 3 (2019): 220-227.

8. Hilary Hughes, Liz Cooper, Michael Flierl, Mary M. Somerville and Niraj Chaudhary, "The Role of the University Library in Supporting International Student Transition: Insights from an Australian-American Case Study," The Journal of Academic Librarianship 44, no. 5 (2018): 582-594.

9. Kavita Pandit, "International Students and Diversity," in International Students and Scholars in the United States: Coming from Abroad, ed. Heike C. Alberts and Helen D. Hazen (New York: Palgrave Macmillan, 2013), 131-141.

10. U.S. Department of Education International Affairs Office, Succeeding Globally Through International Education and Engagement (2018), https://sites.ed.gov/international/internationalstrategy-2/ (accessed February 11, 2021).

11. Stephen R. Covey, The 7 Habits of Highly Effective People (New York: Free Press, 2004). $\pi$ 